\title{
PENGARUH MODEL PEMBELAJARAN INKUIRI DAN KREATIVITAS TERHADAP KETERAMPILAN GENERIK SAINS SISWA DI SMA NEGERI 1 PEUKAN PIDIE
}

\author{
Mainisa dan Ridwan Abdullah Sani \\ Jurusan Pendidikan Fisika Universitas Negeri Medan
}

\begin{abstract}
Abstrak. Penelitian ini bertujuan untuk: (1) Mengetahui perbedaan keterampilan generik sains siswa menggunakan model pembelajaran inkuiri dan pembelajaran konvensional. (2) Mengetahui keterampilan generik sains antara siswa yang mempunyai kreativitas tinggi dan siswa yang mempunyai kreativitas rendah. (3) Mengetahui interaksi antara model pembelajaran inkuiri dengan kreativitas terhadap keterampilan generik sains siswa pada materi alatalat optik. Penelitian ini merupakan jenis penelitian quasi eksperimen. Populasi penelitian ini adalah seluruh siswa kelas X semester II SMA Negeri 1 Peukan Pidie T.A. 2013/2014 sebanyak 5 kelas (152 orang). Sampel penelitian terdiri dari 2 kelas yaitu kelas X-1 (kelas Eksperimen) dan kelas X-4 (kelas kontrol) yang ambil secara cluster random sampling. Instrumen penelitian berupas tes keterampilan generik sains dan tes kreativitas. Data dianalisis menggunakan SPSS 17, hasil pengujian hipotesis ANAVA 2 jalur sebagai berikut: (1) Model pembelajaran Inkuri lebih baik dalam meningkatkan keterampilan generik sains siswa dari pada pembelajaran konvensional. (2) Keterampilan generik sains siswa yang mempunyai kreativitas tinggi lebih baik dibanding dengan siswa yang mempunyai kreativitas rendah. (3) Ada interaksi antara model pembelajaran Inkuiri dengan pembelajaran konvemsional dan kreativitas terhadap keterampilan generik sains siswa.
\end{abstract}

Kata kunci: model pembelajaran inkuiri, kreativitas, keterampilan generik sains

\section{THE EFFECT INQUIRY LEARNING MODEL AND CREATIVITY TO STUDENTS' SCIENCE GENERIC SKILLS IN SMA NEGERI 1 PEUKAN PIDIE}

\author{
Mainisa and Ridwan Abdullah Sani \\ Physics Education Program-State University of Medan
}

\begin{abstract}
This research aimed to: (1) find the difference of student achievement of science generic skills using Inquiry learning model and conventional learning, (2) to figure student achievement of science generic skills between high creativity student with those who had low creativity. (3) to figure the interaction between the creativity and learning model to achievement of science generic skills on optic topic. The population of this research was the entire students of grade X SMA Negeri 1 Peukan Pidie Learning Year 2013/2014, with total amount of 5 classes (152 students). The samples consist of two class, which are class X-1 (experiment class) and class X-4 (control class) were taken by Cluster Random Sampling. The data was
\end{abstract}


analyzed using SPSS 17, and hypothesis is tested using two way ANAVA. The research result shows that: (1) the inquiry learning model was better than conventional learning in improving science generic skills of students. (2) the science generic skills of high creativity student is better than those who had the low creativity. (3) the interaction is exist between creativity and learning model related to the improvement of science generic skills of student.

\section{Keyword: inquiry learning model, creativity, science generic skills}

\section{PENDAHULUAN}

Ilmu Fisika merupakan ilmu yang sarat dengan konsep-konsep dari konsep sederhana sampai ke konsep yang lebih komplek. Pengajaran fisika tingkat SMA menguraikan dan menganalisis struktur dan peristiwa alam, teknik dan dunia sekelilingnya yang semua individu harus berpikir kritis dalam mempelajarinya (Sagala, 2009). Pernyataan tersebut mengisyaratkan bahwa dalam pembe-lajaran fisika perlu memadukan teori dan praktikum sehingga kegiatan pembelajaran lebih bermakna, sebagaimana yang dikemu-kakan oleh Rustaman (2005) bahwa proses belajar dilakukan melalui proses eksplorasi dari pengalaman yang dimilikinya melalui kegiatan ilmiah yang dimulai dengan observasi data primer atau sekunder sampai pada kesimpulan yang menjadi pengetahuan baru.

Berdasarkan hasil studi pendahuluan dan komunikasi langsung dengan guru bidang studi Fisika di SMA Negeri 1 Peukan Pidie diketahui bahwa siswa masih memiliki kemampuan dasar rendah yang ditunjukkan dengan minimnya aktivitas bertanya, menjawab, menanggapi dan mengemukakan pendapat, serta kurangnya kemampuan siswa dalam menyelesaikan soalsoal Fisika. Untuk mengatasi hal tersebut, maka penulis memandang perlu diterapkan suatu model pembelajaran yang dapat melatih kemampuan siswa dalam menyelesaikan masalah, baik yang mereka temui dalam pelajaran fisika maupun dalam kehidupan sehari-hari. Model pembelajaran yang dimaksud adalah model pembelajaran inkuiri.

Dapat dikatakan bahwa inkuiri merupakan suatu model pembelajaran yang digunakan dalam pembelajaran fisika dan mengacu pada suatu cara untuk mempertanyakan, mencari pengetahuan atau informasi, atau mempelajari suatu gejala (NRC, 2000). Tujuan umum dari model pembelajaran inkuiri adalah untuk membantu siswa mengembangkan keterampilan intelektual dan keterampilan-keterampilan lainnya.

Joyce dan Weil (2009) mengemukakan bahwa model pembelajaran berbasis inkuiri suatu proses melatih siswa untuk menginvestigasi dan menjelaskan fenomena yang tidak biasa. Pembelajaran inkuiri didesain sedemikian rupa agar siswa secara langsung yang melakukan proses ilmiah melalui latihan. Syam (2007) mengemukakan bahwa tujuan utama pembelajaran inkuiri adalah untuk memberikan cara bagi siswa untuk membangun kecakapankecakapan intelektual (kecakapan berfikir) terkait dengan proses- proses berfikir reflektif.

Keterampilan generik sains adalah keterampilan berpikir dalam pembelajarn sanis yang digunakan secara umum dalam berbagai kerja ilmiah (Brotosiswoyo, 2000). Keterampilan generik sains merupakan keterampilan berpikir dalam pembelajaran sains yang harus dimiliki setiap siswa. Keterampilan generik juga keterampilan dasar yang wajib dikuasai siswa. Jika kemampuan dasar siswa ini diintegrasikan dengan pengetahuan mengenai sains akan menjadi kompetensi generik yang dapat digunakan untuk mempelajari dan menggunakan berbagai pengetahuan sains dalam berbagai konteks sains untuk memenuhi kebutuhan hidup siswa di berbagai situasi hidupnya (Sunyono, 2009).

Suriani (2007) memperoleh kesimpulan bahwa terdapat pengaruh model pembelajaran 
inkuri terhadap keterampilan generik sains siswa kelas X SMA Negeri 1 Tinombo. Gunawan (2013) menemukan bahwa keterampilan generik sains mahasiswa calon guru yang belajar dengan virtual laboratory lebih tinggi dibandingkan dengan mahasiswa yang belajar secara konvensional. Penelitian oleh Saprudin (2010) memberikan kesimpulan bahwa perolehan skor gain keterampilan generik sains yang diajarkan dengan bantuan multimedia interaktif online dan offline untuk kelas eksperimen diperoleh sebesar 0,72 termasuk dalam kategori tinggi. Selanjutnya, Wirtha dan Rapi (2008) menemukan bahwa penguasaan konsep fisika siswa yang belajar melalui model pembelajaran inkuiri lebih baik dari pada siswa yang belajar melalui model pembelajaran konvensional.

Berdasarkan uraian latar belakang permasalahan diatas, maka masalah pokok yang akan dicari jawabannya dalam penelitian ini yakni: 1) Apakah ada perbedaan keterampilan generik sains siswa menggunakan model pembelajaran inkuiri dan pembelajaran konvensional? 2) Apakah terdapat perbedaan keterampilan generik sains pada siswa yang memiliki tingkat kreativitas tinggi dan pada siswa yang memiliki tingkat kreativitas rendah? 3) Apakah terdapat interaksi antara model pembelajaran inkuiri dengan kreativitas terhadap keterampilan generik sains siswa pada materi alat-alat optik? Penelitian ini bertujuan untuk:1) Untuk mengetahui perbedaan keterampilan generik sains siswa menggunakan model pembelajaran inkuiri dan pembelajaran konvensional. 2) Untuk mengetahui perbedaan keterampilan generik sains pada siswa yang memiliki tingkat kreativitas tinggi dan pada siswa yang memiliki tingkat kreativitas rendah. 3) Untuk mengetahui adanya interaksi antara model pembelajaran inkuiri dengan kreativitas terhadap keterampilan generik sains siswa pada materi alat-alat optik.

\section{METODE PENELITIAN}

Penelitian ini dilaksanakan di SMA Negeri 1 Peukan Pidie Tahun Ajaran 2013/ 2014. Populasi dalam penelitian ini seluruh siswa kelas $\mathrm{X}$ yang berjumlah 152 siswa.
Pengambilan sampel dilakukan secara cluster random sampling sehingga diperoleh kelas X-1 sebagai kelas eksperimen dengan jumlah siswa 30 orang dan kelas X-4 sebagai kelas kontrol dengan jumlah siswa 30 orang. Variabel terikat dalam penelitian ini adalah keterampilan generik sains, variabel bebasnya model pembelajaran inkuiri dan variabel moderatornya kreativitas.

Jenis penelitian ini adalah quasi eksperimen atau eksperimen semu dengan menggunakan desain kolompok kontrol pretest-posttest (pretest-posttest control group design). Desain penelitiannya disajikan pada Tabel 1 .

Tabel 1. Desain Penelitian

\begin{tabular}{cccc}
\hline Kelas & Pretes & Perlakuan & Postes \\
\hline Eksperimen & $\mathrm{T}_{1}$ & $\mathrm{X}_{1}$ & $\mathrm{~T}_{2}$ \\
Kontrol & $\mathrm{T}_{1}$ & $\mathrm{X}_{2}$ & $\mathrm{~T}_{2}$ \\
\hline
\end{tabular}

Keterangan:

$\mathrm{T}_{1}$ : Tes kemampuan awal (pretes)

$\mathrm{T}_{2}$ : Tes kemampuan akhir (postes)

$\mathrm{X}_{1}$ : Perlakuan pada kelas eksperimen yaitu

penerapan model pembelajaran inkuiri

$\mathrm{X}_{2}$ : Perlakuan pada kelas kontrol yaitu

penerapan dengan pembelajaran

konvensional

Teknik yang digunakan dalam pengumpulan data pada penelitian ini adalah melalui tes. Instrumen penelitian yang digunakan adalah soal essay untuk kreativitas siswa dan tes objektif untuk tes keterampilan generik sains. Sebelum pengujian hipotesis, dilakukan uji prasyarat meliputi uji normalitas, homogenitas dan uji hiotesis dua pihak dengan menggunakan software SPSS 17 demikian juga dengan teknik analisis data untuk pengujian hipotesis yang digunakan dalam penelitian ini adalah ANAVA $2 \times 2$. Instrumen kreativitas digunakan untuk membagi siswa dalam kelompok kreativitas tinggi dan rendah dengan menggunakan rumus rata-rata $+1 / 2$ SD (kreativitas tinggi) dan ratarata $-1 / 2$ SD (kreativitas rendah) (Wahidmurni, 2010). Peningkatan keterampilan generik sains sebelum dan setelah kegiatan pembelajaran dihitung dengan rumus $g$ factor (gain score normalized) sebagai berikut:

Gain Ternormalisasi $\langle g\rangle=\frac{\text { Skor postest }- \text { skor pretest }}{\text { Skor maksimum - skor pretest }}$ 
Katagori Gain:

$\mathrm{g}<0,3 \quad:$ kategori rendah

$0,3 \leq g \geq 0,7$ : kategori sedang

$\mathrm{g}>0,7 \quad:$ kategori tinggi

\section{HASIL PENELITIAN DAN PEMBAHASAN \\ Deskripsi Hasil Pretes Keterampilan \\ Generik Sains}

Deskripsi data pretes untuk kelas ekperimen dan kontrol dapat dilihat pada Tabel 2.

Tabel 2.Ringkasan Data Pretes Kelompok Sampel

\begin{tabular}{cccccc}
\hline \multirow{2}{*}{ Kelas } & \multicolumn{4}{c}{ Tes Awal Keterampilan Proses Sains } \\
\cline { 2 - 6 } & $\mathrm{N}$ & $\begin{array}{c}\text { Nilai } \\
\text { Maks. }\end{array}$ & $\begin{array}{l}\text { Nilai } \\
\text { Min. }\end{array}$ & $\begin{array}{c}\text { Re- } \\
\text { rata }\end{array}$ & $\begin{array}{c}\text { Simpa } \\
\text { ngan } \\
\text { Baku }\end{array}$ \\
\hline Eksperimen & 30 & 45,00 & 15,00 & 28,67 & 8,19 \\
\hline Kontrol & 30 & 40,00 & 15,00 & 27,33 & 7,16 \\
\hline
\end{tabular}

Berdasarkan data pada Tabel 2 terlihat bahwa rata-rata nilai pretes pada kelas eksperimen dan kelas kontrol masing-masing adalah 28,67 dan 27,33. Sementara itu, simpangan baku untuk kelas eksperimen adalah 8,19 sedangkan simpangan baku untuk kelas kontrol adalah 7,16. Berdasarkan data tersebut terlihat bahwa rata-rata nilai pretes kelas eksperimen sedikit lebih besar dibandingkan dengan rata-rata nilai pretes kelas kontrol.

Selanjutnya dilakukan uji hipotesis dua pihak data pretes untuk melihat kemampuan awal siswa baik kelas ekperimen dan kelas kontrol. Selengkapnya dapat dilihat Tabel 3.

Tabel 3. Uji Hipotesis Dua Pihak Pretes

\begin{tabular}{lcc}
\hline & $\begin{array}{c}\text { Levene's } \\
\text { Test }\end{array}$ \\
\hline $\begin{array}{l}\text { NILAI PRETES Equal variances } \\
\text { assumed }\end{array}$ & $\mathrm{T}$ & Sig. \\
\hline Equal variance not assumed & -.67 & .51 \\
\hline
\end{tabular}

\section{Deskripsi Perbandingan Indikator Kreativitas}

Berdasarkan hasil perhitungan nilai kreativitas siswa, diperoleh hasil untuk kelompok kategori kreativitas tinggi sebanyak 16 orang untuk kelas eksperimen dan 15 orang untuk kelas kontrol sedangkan kelompok kreativitas rendah berjumlah 14 orang untuk kelas ekperimen dan 15 orang untuk kelas kontrol.
Persentase tingkat kreativitas hampir setiap indikator lebih tinggi dimiliki oleh kelas eksperimen kecuali pada keteramplan berpikir lancar. Indikator yang dominan muncul adalah keterampilan menilai sebesar $86,7 \%$ di kelas eksperimen dan $84,4 \%$ di kelas kontrol, sedangkan yang paling rendah adalah sifat meghargai yaitu $60,7 \%$ di kelas eksperimen dan $58,00 \%$ di kelas kontrol.

\section{Hasil Postes Keterampilan Generik Sains}

Deskripsi data postes untuk kelas ekperimen dan kontrol dapat dilihat pada Tabel 4.

Tabel 4. Ringkasan Data Postes

Kelompok Sampel

\begin{tabular}{cccccc}
\hline \multirow{2}{*}{ Kelas } & \multicolumn{5}{c}{ Tes Akhir (Postes) } \\
\cline { 2 - 6 } & $\mathrm{N}$ & $\begin{array}{r}\text { Nilai } \\
\text { Maks. }\end{array}$ & $\begin{array}{l}\text { Nilai } \\
\text { Min. }\end{array}$ & $\begin{array}{c}\text { Re- } \\
\text { rata }\end{array}$ & $\begin{array}{c}\text { Simpa } \\
\text { ngan } \\
\text { Baku }\end{array}$ \\
\hline Eksperimen & 30 & 95,00 & 45,00 & 75,83 & 14,20 \\
\hline Kontrol & 30 & 90,00 & 40,00 & 70,67 & 11,04 \\
\hline
\end{tabular}

Berdasarkan data pada Tabel 4. terlihat bahwa rata-rata nilai postes pada kelas eksperimen dan kelas kontrol masing-masing adalah 75,83 dan 70,67. Sementara itu, simpangan baku untuk kelas eksperimen adalah 14,20 sedangkan simpangan baku untuk kelas kontrol adalah 11,04. Berdasarkan data tersebut terlihat bahwa rata-rata nilai postes kelas eksperimen lebih besar dibandingkan dengan rata-rata nilai postes kelas kontrol.

Berdasarkan hasil perhitungan gain ternormalisasi, secara umum peningkatan keterampilan generik sains siswa di kelas ekperimen sebesar 0,67 termasuk dalam kategori sedang dan di kelas kontrol sebesar 0,60 termasuk dalam kategori sedang. Kedua kelas menunjukkan peningkatan yang hampir sama akan tetapi lebih tinggi gain yang diperoleh kelas eksperimen. Hal ini disebabkan penyelidikan sederhana yang dilakukan pada pembelajaran inkuiri mengharuskan siswa memahami bahasa simbolik yang ada dalam variabel yang ingin dicari. Hasil penyelidikan mengarahkan siswa pada pembuatan grafik dari simbol besaran yang diteliti. 
Hasil postes keterampilan generik sains siswa pada kelas eksperimen dan kontrol dapat dilihat berdasarkan indikator keterampilan generik sains. Hasil gain keterampilan generik sains juga dapat dilihat berdasarkan tiap indikator. Indikator keterampilan generik sains siswa yang termasuk kedalam kategori tinggi pada kelompok eksperimen adalah pada indikator pengamatan langsung sebesar 0,81 dan yang termasuk kedalam kategori sedang adalah indikator pemodelan matematika sebesar 0,55. Hal ini disebabkan pembelajaran model inkuiri menekankan pada proses mengamati fenomena fisika secara langsung. Melalui pengamatan langsung, siswa mencermati dan membuat perkiraan-perkiraan awal tentang fenomena tersebut yang nantinya akan diuji cobakan dalam praktikum.

Gain tiap indikator keterampilan generik sains di kelas kontrol memiliki gain tertinggi adalah pemodelan matematika sebesar 0,78 dan yang termasuk kategori sedang adalah pengamatan tidak langsung sebesar 0,51. Dampak yang kurang baik dari pembelajaran konvensional adalah kurangnya perhatian pada pengembangan kemampuan logika siswa. Siswa jadi kurang mampu menalar jika dihadapkan pada permasalahan yang berhubungan dengan konsep-konsep fisika.

Pengujian hipotesis penelitian dengan menggunakan uji ANAVA faktorial 2x2 dengan bantuan SPSS 17.0 for windows. Ringkasan outputyang digunakan untuk menguji hipotesis dalam penelitian ini dapat dilihat pada Tabel 5.

Tabel. 5. Hasil Uji Anava

\begin{tabular}{lrrrr}
\hline \multicolumn{1}{c}{ Jumlah Variasi } & df & $\begin{array}{c}\text { Ke- } \\
\text { Kuadrat }\end{array}$ & \multicolumn{1}{c}{ F } & Sig. \\
\hline Model pembelajaran & 1 & 281.04 & 5.06 & .03 \\
\hline Tingkat kreativitas & 1 & 5887.28 & 105.98 & .00 \\
\hline $\begin{array}{l}\text { Model pembelajaran } \\
\text { dengan tingkat kreativitas }\end{array}$ & 1 & 399.53 & 7.19 & .01 \\
\hline Interaksi & 56 & 55.55 & & \\
\hline
\end{tabular}

Berdasarkan Tabel 5, dapat disimpulkan berdasarkan masing-masing hipotesis sebagai berikut:

\section{Hipotesis Pertama}

Berdasarkan perhitungan anava faktorial $2 \times 2$ diperoleh nilai signifikan model pembelajaran 0,03 . Oleh karena sig $(0,03)<\alpha=(0,05)$ sehingga pengujian hipotesis menolak $\mathrm{H}_{0}$ dan terima Ha. Kesimpulan yang bisa diambil adalah terdapat perbedaan keterampilan generik sains siswa menggunakan model pembelajaran inkuiri dan pembelajaran konvensional. Hal ini terlihat dari rata-rata postes keterampilan generik sains siswa yang dibelajarkan dengan menggunakan model pembelajaran inkuiri $(\bar{x}$ pos包es $=75,83)$ lebih tinggi dari keterampilan generik siswa yang dibelajarkan dengan menggunakan pembelajaran konvensional $(\bar{x}$ posEes $=70,67)$.

\section{Hipotesis Kedua}

Berdasarkan perhitungan anava faktorial $2 \times 2$ diperoleh nilai sig. tingkat kreativitas adalah 0,00 . Oleh karena nilai sig. $(0,00)<\alpha=$ $(0,05)$ sehingga pengujian hipotesis menolak $\mathrm{H}_{\mathrm{O}}$ atau menerima $\mathrm{Ha}$ pada taraf alpha $5 \%$. Kesimpulan yang dapat diambil adalah terdapat perbedaan keterampilan generik sains pada siswa yang memiliki tingkat kreativitas tinggi dan siswa yang memiliki tingkat kreativitas rendah. Rata-rata postes keterampilan generik sains siswa yang memiliki tingkat kreativitas tinggi $(87,50)$ lebih tinggi dari keterampilan generik siswa yang memiliki kreativitas rendah $(62,50)$.

\section{Hipotesis Ketiga}

Berdasarkan Tabel 5 pada kategori baris interaksi model pembelajaran dengan tingkat kreativitas diperoleh nilai Sig. 0,01. Oleh karena nilai Sig. $(0,01)<\alpha=0,05$, maka dapat dikatakan bahwa hasil pengujian menolak Ho dan atau menerima Ha dalam taraf alpha 5\%. Dengan demikian dapat disimpulkan bahwa terdapat interaksi antara model pembelajaran Inkuiri dengan kreativitas terhadap keterampilan generik sains siswa pada materi alat-alat optik.

\section{SIMPULAN}

1. Model pembelajaran inukiri lebih baik dalam meningkatkan keterampilan generik sains siswa dari pada pembelajaran konvensional. 
Berdasarkan hasil keterampilan generik sains yang telah dicapai oleh kelas ekperimen dan kelas kontrol, yaitu terdapat perbedaan hasil keterampilan generik sains antara kelas ekperimen dan kelas kontrol. Kelas ekperimen mengalami peningkatan gain ternormalisasi rata-rata sebesar 0,67 dengan kategori sedang dan kelas kontrol mengalami peningkatan gain ternormalisasi rata-rata sebesar 0,60 dengan kategori sedang.

2. Hasil keterampilan generik sains siswa yang memiliki tingkat kreatifitas tinggi lebih baik dibandingkan dengan keterampilan generik sains siswa yang memiliki tingkat kreatifitas rendah. Perolehan indikator yang memiliki persentase paling tinggi adalah keterampilan menilai sebesar $86,67 \%$ di kelas eksperimen dan $84,44 \%$ di kelas kontrol, sedangkan yang paling rendah adalah sifat meghargai yaitu $60,67 \%$ di kelas eksperimen dan $58,00 \%$ di kelas kontrol.

3. Terdapat interaksi model pembelajaran inkuiri dan konvensional dengan tingkat kreativitas terhadap keterampilan generik siswa. Kreativitas pada siswa yang diajarkan dengan pembelajaran konvensional tidak berperan, hal ini dapat dilihat dari hasil keterampilan generik sains yang diperoleh siswa masih rendah baik pada siswa yang memiliki tingkat kreativitas tinggi dan tingkat kreativitas rendah. Sedangkan kreativitas siswa yang diajarkan dengan model pembelajaran inkuiri sangat berperan.

\section{DAFTAR PUSTAKA}

Brotosiswoyo, B.S. 2000. Hakekat Pembelajaran Fisika di Perguruan Tinggi, dalam Hakekat Pembelajaran MIPA \& Kiat Pembelajaran Fisika di Perguruan Tinggi. Jakarta: Proyek Pengembangan UT. Depdiknas.

Gunawan, Agus Setiawan, Dwi H. Widyantoro. 2013. Model Virtual Laboratory Fisika Modern Untuk Meningkatkan Keterampilan Generik Sains Calon Guru. Jurnal Pendidikan Dan Pembelajaran (Jpp), Vol. 20, No 1.
Joyce, B., Weil,M. \& Calhoun, E. 2009. Models of Teaching $8^{\text {th }}$ ed. Model-model Pengajaran (Terj. Achmad Fawai \& Ateilla Mirza). Yogyakarta: Pustaka Pelajar.

NRC. 2000. National Sains Education Standard. Washington.D.C: National Academi Press.

Rustaman. 2005. Perkembangan Penelitian Pembelajaran Berbasis Inkuiri Dalam Pendidikan Sains. (Online) Tersedia: http://file.upi.edu/direktori/sps/pendidikan diakses 10 Februari 2014.

Sagala, S. 2009. Konsep dan Makna Pembelajaran. Bandung: Alfbeta.

Saprudin, Sutarno, Liliasari. 2010. Developing Generic Science Skills Of Prospective Teacher Through Offline and Online Interactive Multimedia in Physics Learning. Proceding of the $4^{\text {th }}$ International Conference on Teacher; Join Conference UPI \& UPSI Bandung. Indonesia 8-10 November 2010.

Sunyono. 2009. Pembelajaran IPA dengan Keterampilan Generik Sains, (Online) diakses melalui situs: Documents $\% 20$ and\%20Settings/IMC/My\%20keterampila n\%20generik\%20sains.htm, diakses 2 September 2013.

Suriyani. 2007. Pengaruh Model Pembelajaran Inkuiri Terhadap Keterampilan Generik Sains Dan Hasil Belajar Siswa Kelas X SMA Negeri 1 Tinombo. Jurnal Pendidikan: Mitra Sains ISSN: 2302-2027.

Syam. 2007. Praktikum Inkuiri. Makalah/bahan kuliah tidak dipublikasikan. Bandung: SPs. UPI.

Wahidmurni. 2010. Evaluasi Pembelajaran Kompetensi dan Praktik. Yogyakarta: Nuha Litera.

Wirta, M.I. dan Rapi, K.N. 2008. Pengaruh Model Pembelajaran dan Penalaran Terhadap Penguasaan Konsep Fisika dan Sikap Ilmiah Siswa SMAN 4 Singaraja. Jurnal Pendidikan FMIPA Undiksha. 1(2), 15-29. 